\title{
D.T. Suzuki at the World Congress of Faiths in 1936
}

\section{An Analysis of His Presentation at the Interfaith Conference}

\author{
Moriya Tomoe 守屋友江 | ORCID: 0000-0001-9927-2441 \\ Nanzan Institute for Religion and Culture, Nagoya, Japan \\ tmoriya@nanzan-u.ac.jp
}

\begin{abstract}
This paper examines the speeches that D.T. Suzuki presented at the World Congress of Faiths in London in 1936 and analyzes his interactions with Buddhists, sympathizers, and critics in the West during the interwar period. It will uncover how various reactions and historical contexts constructed Suzuki's discourses, which prepared Suzuki for popularizing Zen in postwar Western countries. Compared to his early years and post-1949 lectures in the United States, as well as his English publications on Mahayana Buddhism, his half-year journey through Europe in 1936 is understudied. With limited access to primary sources in Japanese and English, previous studies tended to label him a "nationalist." Instead, I analyze Suzuki's discourses and other newly discovered primary sources from a historical perspective. Through this analysis, this paper will clarify Suzuki's scheme to present Mahayana Buddhism, particularly Zen, to Westerners during the interwar period.
\end{abstract}

\section{Keywords}

D.T. Suzuki - World Congress of Faiths - Western perception of Buddhism - interfaith dialogue - Dunhuang manuscripts - Senzaki Nyogen

\section{Introduction}

Suzuki Daisetsu Teitarō 鈴木大拙貞太郎 (1870-1966), better known as Daisetz Teitaro Suzuki in the West, traveled to prewar Europe in his thirties and again in his sixties; he traveled to London and Oxford in 1908, and then attended the World Congress of Faiths in July 1936. This paper deals with the latter 
experience, examining his speeches and discussions with participants at the Congress. Although his postwar lectures at American universities and his numerous publications on Buddhism in English are well-known as a catalyst for the Zen boom in the West, his six-month stay in Europe in 1936 remains relatively understudied. Some of the recent studies on Suzuki's discourses from the 1930s to early 1940s do not necessarily refer to this half-year journey, but depict him as nationalist (Sharf 1994), reverse Orientalist (Faure 1995), pro-war (Victoria 1997), and even pro-Nazi (Victoria 2013).

Although Suzuki did travel to Nazi Germany for a week after the London event ended, instead of hastily jumping to the conclusion that he was proNazi, this paper analyzes his discourses and other newly discovered materials, including those from the Matsugaoka Bunko 松ヶ岡文庫 in Kamakura and what I found at the Zen Buddhist Society in New York. ${ }^{1}$ Through this analysis, I clarify Suzuki's scheme to present Mahayana Buddhism to Westerners and consider the meaning of these interactions in the interwar period.

\section{Background of the Interfaith Conference}

The 1936 World Congress of Faiths, an interfaith conference organized by Francis Edward Younghusband (1863-1942), was modeled after the 1893 World's Parliament of Religions in Chicago. The 1936 event was attended by such scholars and members of the clergy as Sarvepalli Radhakrishnan of Oxford University, Frank Russell Barry of Westminster Abbey, Halidé Edib from Turkey, and Rom Landau. Landau was the author of the best-selling God is My Adventure (1935), which was a collection of his encounters with philosophical and spiritual figures like Hermann von Keyserling, Rudolf Steiner, Jiddu Krishnamurti, Meher Baba, and George Ivanovich Gurdjieff. The majority of the 65 listed participants came from a Christian background, with others coming from Hinduism, Islam, and Judaism. The Buddhist-related participants included Anesaki Masaharu 姉崎正治 of Tokyo Imperial University, Gunapala Piyasena Malalasekera of Ceylon University, Alan Watts as an editor of Buddhism in England, Caroline Augusta Foley Rhys Davids, and Suzuki. ${ }^{2}$

1 All translations of cited works by Japanese authors are mine except for those originally written in English. I use American spelling, except for sources originally written in British English. For the romanization of Chinese terms, I use modified Pinyin.

2 Anesaki, Rhys Davids, and Watts did not present their papers. Anesaki was attending the League of Nations committee to give a talk in Geneva on 13 July 1936 (Takahashi 20o9: 9). 
Younghusband was a British Army officer and adventurer who, during the British invasion of Tibet in 1903-1904, massacred thousands of Tibetans including monks, and was subsequently promoted to Knight Commander in 1904. Following some mystical and occult visions, he sought spiritual guidance through telepathy. About a decade later, during World War I, he founded the Fight for Right Movement, explaining that "There seemed ... to be scope for an organization whose business it would be continually to remind the nation of the ideals and principles for which we were fighting; ... and to sustain and heighten the spirit of the people in this great fight" (Younghusband 1918: iii-iv).

The consequences of the war were not as simple as his "ideal" of the right cause, and democracy in the Weimar Republic collapsed as the Nazi Party rose to power in the mid-193os. Nicolas Berdiaeff, a Russian exile, spoke to the World Congress of Faiths: "At present, a kind of hatred is increasing throughout the world, which, far from being restricted to Christianity, assails all religions ... We all know what is happening in this respect in Soviet Russia, in Hitlerian Germany and in Mexico" (Berdiaeff 1936: 81). A pacifist American rabbi, Judah Leon Magnes, also addressed the Congress, saying that, "If you ask me, a Jew, what I would do if Germany was now at war, I confess that I very often feel that I must enlist against her. I pray that I might be given the strength to overcome this temptation and resist the war, [for] I do not know how ... We are so poor of mind and character that despite all our power we know of no other effective way than the use of force in international relations" (Magnes 1936: 266).

In light of such historical conditions, Younghusband came to stress the importance of "unity between religions" and overcoming "an exclusive hold on truth" in each religion (Jaffe 2018: 35). Thus, with some anticipation of receiving monetary assistance from the wealthy American philanthropist Charles R. Crane (Jaffe 2018: $36-37$ ), Younghusband contacted various figures, mostly UK-based individuals, from different religious and philosophical backgrounds in order to hold the Congress in London.

Yet according to Richard Jaffe (2018: 37), Suzuki was initially reluctant to travel to London because he was preoccupied with ongoing projects related to early Zen manuscripts discovered at Dunhuang. Such hesitation was understandable considering Suzuki's numerous text-critical studies in Japanese and English at that time. In 1921, Suzuki transferred to Shin Buddhist affiliated Otani University, where he "entered one of the most productive periods of his writing career" (Jaffe 2010: xi). His bibliography, compiled by Kirita Kiyohide, lists several annotated studies on the Sayings of Shenhui (Jp. Jin'ne goroku 神会 語録; Ch. Shenhui yulu) (1932-1934), the Record of Master and Disciple in (the Transmission of) the Lankka (Jp. Ryōga shijiki 楞伽師資記; Ch. Lengqie shizi ji, 
1933), ${ }^{3}$ and the Platform Sutra of the Sixth Patriarch (Jp. Rokuso dankyō 六祖壇 経; Ch. Liuzu tanjing) (1933-1934), as well as English works like Studies in the Lankavatara Sutra (1930) and a translation of the Lankkāvatära Sütra (1932). All of these were published in book form in the early 193 os (Kirita 2005: 35-48).

Suzuki also edited a collotype version of Shōshitsu issho 少室逸書 (Ch. Shaoshi yishu), containing six writings of Zen history and sayings by early Zen masters, which he acquired in Beijing in 1934 and published via a private printer the following year (Suzuki 1935). Although for unknown reasons Suzuki's name was not included on the cover as a translator, he helped considerably with the English translation of Tokiwa Daijō 常磐大定's Bukkyō shiseki 仏教史蹟 series, published as Buddhist Monuments in China from 1926 to 1938 (Watanabe 2016: 43-46). He then published an annotated edition of Shōshitsu issho with articles on Bodhidharma in June 1936 (Suzuki 1936d), just about the time he departed for Europe (Kirita 2005: 50). In several letters to Senzaki Nyogen 千 崎如幻 (1876-1958) in Los Angeles, possibly written in the mid-193os, Suzuki asked how his new findings, detailed in Shōshitsu issho and Song of Enlightenment, or Shōdōka 証道歌 (Ch. Zhengdao ge) from Dunhuang, could help Senzaki and American Zen practitioners understand Zen Buddhism. ${ }^{4}$ These letters coincided with his cooperation in establishing and assisting Gaijin Zenkutsu 外人禅窟 (translated as the Foreign Buddhist Hospice) in Kyoto (Jaffe 2018: 33; Yoshinaga 2019:3).

In response to a request from Younghusband, Crane promised to cover the travel fees for Suzuki's trip to London and Paris in order to investigate the Dunhuang manuscripts at the British Museum and National Library of France respectively and to lecture in the United States afterwards. Soon after, in February 1936, Suzuki accepted both Crane's offer and Younghusband's invitation (Jaffe 2018: 37; Kirita 2005: 92). As Suzuki wrote to his friend Yamamoto Ryōkichi 山本良吉 (1871-1941) on 1 May 1936, “I am traveling [to Europe] with generous funding from an American ... because I anticipate taking a look at

3 The English title for Ryōga shijiki is as in Suzuki (1932: xlv). These books were actually compilations of articles previously published, many of them in the Eastern Buddhist in the 1920s.

4 The letters from Suzuki to Senzaki at the Zen Studies Society Archive are dated by month and day, but not year, nor do they have envelopes from which to identify the year in which they were sent. Making educated guesses from the content, the letters regarding Shōshitsu issho, dated August 10 and September 10, are from 1936; on Shōdōka, dated February 8, (year unknown); October 14, (1936), n.d. (1941). Folder 1, Nyogen Senzaki Papers, Box 3, Zen Studies Society Archives. Senzaki, together with his student, Ruth Strout McCandless (19o9-1994), later published a translation of the Shōdōka written by the early Chan master Yongjia Xuanjie 永嘉玄覚 (665-713) in their co-authored book Zen and Buddhism (New York: Philosophical Library, 1953). They translated the title as Song of Realization. 
the Dunhuang manuscripts" (sDz 36: 620). He boarded the Hiei from Yokohama and crossed the Pacific to travel to London via the United States on 4 June 1936 (Kirita 2005: 95). Thus began sixty-six-year-old Suzuki's six-month tour in Europe and America.

\section{Address on "Ignorance"}

The World Congress of Faiths had a prolonged schedule, lasting from 3 to 17 July. Suzuki delivered his speeches at the "welcome meeting" and a lecture on "The Supreme Spiritual Ideal," both of which were open to public, in addition to his solo speech entitled "Ignorance and World Fellowship."5 As shown in Table 1, Suzuki's talk was scheduled second. Among the intellectuals and clergies from East and West who presented their papers at the Congress, he was one of the few participants who did not discuss religion from within a monotheistic framework. He also emphasized the characteristics of Buddhism that distinguished it from other religions, instead of discussing superficial common features.

Suzuki began his talk by describing the "Ignorance" inherent in every human being: "To state that Action starts from Ignorance, or that, dependent on Ignorance there is Action, means that the world where we live and carry on our business is the product of Ignorance ... The aim of the Buddhist discipline is to overcome Ignorance, which is also freeing oneself from Karma, and all its consequences" (Suzuki 1936a: 34-35). Instead of presenting positive, idealistic ideas on "world fellowship" through religion, he first raised the question of the human mindset and how Ignorance causes discrimination and hinders the human mind from achieving Enlightenment. With the Western oversimplification and misunderstanding of Nirvana as death in mind, he explained, "To seek Enlightenment by negating the world, a world of birth and death, is really a deception ... Buddhism accepts life as it is, faces its dualism, its evils, its struggles, its pains, in fact everything that makes it up" (Suzuki 1936a: 38).

Similarly, in a discussion following his speech, the then-twenty-one-year-old Alan Watts (1915-1973) responded, saying:

5 The welcome meeting was held on 3 July, the public meetings on "The Supreme Spiritual Ideal" were held on the 6th and 9th (Suzuki delivered his speech on the latter date), and Suzuki's solo address was given in the afternoon on the 6th. Five other presenters of the public addresses were Canon Frank Russell Barry, Rabbi Israel Mattuck, Sarvepalli Radhakrishnan, Halidé Edib, and Rom Landau. 
TABLE 1 Titles of speeches and presenters at the congress

1. The Essential Basis of Religion

2. Ignorance and World Fellowship

3. An Inspiring Vision

4. The Brotherhood of Man and the Religions

5. Love: The Basis of Fellowship

6. Religion and Religions

7. Science and Religion

8. A Hindu View of Religion

9. Islam and World Fellowship

10. The City of God

11. Prayer and Spiritual Experience

12. A New Pilgrim's Progress

13. Is World Fellowship Possible in View of the Antagonisms of the World?

14. The Teaching of Confucius and His Followers

15. The Spirit of Peace and the Spirit of War

16. Independent Religious Thought

17. Baháulláh's Ground Plan of World Fellowship

18. The Economic Barriers to Peace

19. A Constructive Proposal

20. The Right of the Spirit
A. Yusuf Ali

Daisetz Teitaro Suzuki

G.P. Malalasekera

Nicolas Berdiaeff

M. Saurat

Sarvepalli Radhakrishnan

J.S. Haldane

S.N. Das Gupta

Abdul Qadir

J.S. Whale

Mahendra Nath Sircar

Ranjee G. Shahani

W.J. Stein

S.I. Hsiung

Judah L. Magnes

M. Jean Schlumberger

Shoghi Effendi

P.T.R. Kirk

Sheikh Al-Maraghi

J. Emile Marcault

A. DOUglas MILlARD, ED., FAITHS AND FELLOWSHIP, 1936

For some years, a mere handful of Buddhist students have been insisting that Buddhism in its most essential form is not an escapist philosophy. Some critics have told them that they have been gazing through the rosecoloured spectacles of uninformed enthusiasm, that they have been trying to give Buddhism a Western interpretation, which the facts simply do not fit.

WATTS 1936: 48-49

Ignorance, in this sense, was not just a lack of knowledge, but also a reality of misperception common to every one of us. Suzuki described it as "regarding dualism as final and clinging to it as the basis of our communal life. This logically and emotionally ends in egotism and all the evils flowing from its assertion. Buddhism asks us to gain an insight into that which underlies all 
forms of dualism and thereby not to be attached to them as irreducively [sic] final" (Suzuki 1936a: 38).

Assuming that the majority of participants were Christian, Suzuki elaborated that Emptiness, or Śünyatā, was neither God nor the capitalized "Universal" and was not to be "conceived atheistically, nor pantheistically, nor acosmistically" (Suzuki 1936a: 39). Such seemingly redundant negations may sound clumsy by today's standards, but they would likely have spurred the audience of the 193os to question their concept of "religion." Suzuki kept from specifying a certain people or group, which would circumvent the conclusion that every single person is destined to remain in a state of Ignorance. When compared to speeches by other presenters, his purpose may become more obvious. For example, the president of Cheshunt College, John Seldon Whale (1896-1997), stressed the importance of unity and harmony in the Abrahamic religions, without mentioning Asian religions, because "Religion is rooted in Revelation. It asserts that there is a Word from the Beyond for our predicament, a Gospel of God's mighty acts and of His mightiest act of grace in Time" (Whale 1936: 189-19o). Likewise, a Catholic Archbishop reacted to Suzuki's speech during a discussion: "We have just heard from the East the way out of Karma. Now we do not need to go to the East, for in our own prophet, Jesus Christ, we have the answer" (van Ryswyck 1936: $5^{2}$ ).

Speaking of non-duality, Suzuki explained śūnyatā in relation to a dualistic worldview, using a formula of Byōdō soku shabetsu, shabetsu soku byōdō 平等即差別、差別即平等 (equality in difference, difference in equality). $\mathrm{He}$ explained that byōdō means evenness or sameness whereas shabetsu is individuality, particularity, or multiplicity. Therefore, śünyatā (which he defined as byōdō) is "that which lies underneath pluralistic existences"; furthermore, although individuals "always remain individuals in a dualistically-conditioned world, they are not the same in the sense that you are I and I am you, for you and I are antithetical and their merging into each other is the end of the world. But this does not mean that there is no bridging between the two terms, for if there were no bridging, there would be no mutuality, and consequently no communal life" (Suzuki 1936a: 42). In other words, he interpreted the formula as each person or religion having equal value, yet different features.

As such, how can we understand one another and live our "communal life" in this "dualistically-conditioned world" more meaningfully in a Buddhist way? The answer was the work of "love," or karuna $\bar{a}{ }^{6}$ As a promoter of non-dualism,

6 Though usually translated as "compassion" today, Suzuki used the word "love" to mean karunā at the conference. 
Suzuki did not separate the "spirit" from the "material" and instead discussed how religion could engage in "communal life" because a Buddhist's final goal was not to retreat to remote mountains as a hermit. Although he regarded substance or matter as being able to "help us grow stronger in spiritual power" and therefore "we feel fellowship and mutuality," he warned that "love" without realizing one's own Ignorance could be harmful from a Buddhist point of view (Suzuki 1936a: 44-45).

Suzuki continued his discussion on Buddhist social engagement as follows:

As to the management of the so-called material world, together with our communal life, national and international, which is based on matter, it is left to the best judgments of "worldly" wise people. The only direction Buddhism can give them is to remind them of the truth that as long as Ignorance, taken in its widest possible sense, has a firm hold of us, we are never able to rise above its most undesirable and most deplorable consequences. All these consequences are in fact the outcome of "love" wrongly directed by Ignorance.

SUZUKI 1936a: 45

Although this may seem defeatist and unsatisfactory from an activist-minded perspective, it was inevitable considering his vehement opposition to the political maneuvering of religion, as in the case of "official Shinto" that was "highly colored with political and military motives" (Suzuki 2016c: 68-69). Instead, what Buddhists could tell the "worldly" people was that public-spiritedness "is all very well as far as it goes, but when it implies egotism of a fierce kind, and tends to exclusiveness at all costs, we know where it finally ends. We are just witnessing it practically demonstrated all over the world" (Suzuki 1936a: 46).

In terms of social issues, one of Suzuki's socialist-leaning essays in the $1930 \mathrm{~s}$ can help us better understand his intentions. For instance, his 1930 essay on poverty promoted guaranteeing a fair social welfare system and the equal distribution of wealth, which is understandable given his sympathy toward socialism in his youth and the Japanese Marxists' challenge from the anti-religious movements in the early 1930s. He called for free tuition and medical care, equal pensions for all, sanitary infrastructure, public health care coverage, and even the prohibition of private land ownership. ${ }^{7}$ According to Suzuki,

7 Despite these progressive claims, he approved compulsory eugenic sterilization of people deemed "genetically unfit" in the same essay —an idea prevalent at that time. 
In order to truly fight poverty, the best way is to end poverty itself ... I think religion's role is to encourage us to think about how we can find a way out ... We can also end war, if we want to. It [war] happens due to a lack of religious mind. Out of the budget for war and armaments we can accumulate quite an amount of money. It is possible to raise the same amount within a few years by improving our social life. ${ }^{8}$

SUZUKI 2012a: 205

Therefore, Suzuki believed that one of religion's crucial jobs was to "let the whole world realize how desirable it is to be free from poverty and make progress toward total disarmament by persuading people how absurd war is" (Suzuki 2012a: 205). ${ }^{9}$

At the end of his speech, Suzuki suggested that one possible solution would be establishing a "world-fellowship of faiths" that "have free communication of all kinds among religiously-aspiring people of different nations" (Suzuki 1936a: 47). He proposed it as being independent of existing political bodies and institutions, hinting that these had no visible achievement even after the naval disarmament conferences or the establishment of the League of Nations, of which Japan had been a charter member until 1933 (withdrawal enacted in 1935), because "our Karma-hindrance still weighs on us too heavily" (Suzuki 1936a: 47). Such an idea of religious fellowship had already appeared in an Eastern Buddhist editorial note announcing the establishment of the "International Buddhist Union" by the Buddhist Society of Great Britain and Ireland on 4January 1922, concluding that "we are in full sympathy with the [Buddhist Review] editors in their idea of forming the International Buddhist Union" (Eastern Buddhist Society 1922: 391). ${ }^{10}$ Suzuki wrote to London, "The idea of the Interna-

8 Although I do not detail it here, Suzuki described the Shinkō Bukkyō Seinen Dōmei 新 興仏教青年同盟 (Rising Young Buddhist Alliance) and the Han Shūkyō Tōsō Dōmei 反宗教闘争同盟 (Anti-Religious Struggle Alliance) in a letter to James Bissett Pratt of Williams College, who was a frequent contributor to the Eastern Buddhist. He described the former as "radical but not against Buddhism." Suzuki to Pratt, 27 June 1933 (sDZ 36 : 599).

9 This practical application of nondualism may remind us of his arguments of religion's crucial role and relationship with science, philosophy, society, family, and the state in Shin shūkyō ron 新宗教論 (New Interpretation of Religion), which the young Suzuki wrote in 1896 (Suzuki 2016a). For more on his views on Buddhist social engagement, see Suzuki (2012a).

10 This Buddhist Society was formed in 1907 with Thomas W. Rhys Davids as the president and was different from the Buddhist Society (originally the Buddhist Lodge) founded by Christmas Humphreys in 1924 (Bluck 2006: 7). Bluck described the former was "ailing" by the 1920s, citing Humphreys' memoirs to support his claim (Bluck 2006: 7), but the 
tional Buddhist Union is a fine one, and we heartily subscribe to it. The world knows what Christianity teaches, and it is the time now for Buddhists to proclaim what they think about life and humanity and the future of the world" (Eastern Buddhist Society 1922: 393).

More than a decade later, it was his turn to present a Buddhist's perspective of "life and humanity and the future of the world" before the predominantly Christian audience in London. He concluded the post-talk discussion as follows:

Mere talking does not do much good. But our coming together [does] a great deal. Your seeing my face, and my seeing yours, that does some good. Somehow, arrangements must be made so that we can assemble wherever we want and whenever we want. Unless we can do this, [the] World Fellowship is nothing but talking. We must have these kinds of gatherings, so that in the streets of London they shall know that our Parliament for Peace is meeting here.

SUZUKI 1936b: 53, parenthesis added by author

Such an aspiration for free discussion ( jiy ū tōkyū 自由討究) may remind us of the mission statement of the Shin Bukkyōto Dōshikai 新仏教徒同志会 (New Buddhist Society), in which the young Suzuki was part of the steering committee (Moriya 2005: 287, 291). In fact, the "free" discussion must have been a profound desire for him as he had witnessed "the emergence of an era of terrorism," or the attempted coup d'état in Japan to establish an ultranationalist junta in February 1936. ${ }^{11}$ A group of Army officers of the Imperial Way Faction, influenced by propaganda of the Shōwa Restoration (Shōwa ishin 昭和維新), assassinated ministers and an Army general. Suzuki's diary following the February 26 Incident reveals how he felt "uneasy" about the "terrible political coup d' etat [sic]" (Kirita 2011: 6).

Eastern Buddhist editorial noted that the Society had actively corresponded with other Buddhist organizations around the world and established a network among more than twenty countries and regions (Eastern Buddhist Society 1922: 391-392).

11 Suzuki to Yamamoto, 27 February 1936 (SDZ 36: 618). 


\section{Suzuki and the Western Perception of Buddhism}

As in the study of the British interpretation of Buddhism in the Victorian era, Buddhism became a "textual object" exemplified in Eugène Burnouf's (18011852) Introduction to the History of Indian Buddhism (1844), and several studies of Chinese, Mongolian, Sanskrit, and Tibetan texts, in addition to Pali, started to appear thereafter (Almond 1988: 25). In nineteenth-century Europe, "Buddhism" was, in a sense, "discovered" in these sacred books of the East in various languages, just as King has identified "textualism" in Indology and Buddhist studies (King 1999: 64-72). Although not truly academic in nature, popularized images of Buddhism by Edwin Arnold (1832-1904) demonstrated that history mattered in dealing with the ancient Indian sage (Almond 1988: 54-79). His widely read The Light of Asia (1879) generated interest in Buddhism and the life and philosophy of Prince Siddhārtha, or "the Lord Buddha," which were yet unknown to the Western public. In his preface, Arnold clarified that the verses depicting the historical Buddha were written "by the medium of an imaginary Buddhist votary," but he put the poem into "a Buddhist's mouth, because, to appreciate the spirit of Asiatic thoughts, they should be regarded from the Oriental point of view" (Arnold 1998: 1-4).

On the other hand, in delineating Buddhist history after its "decline" in India, Thomas W. Rhys Davids (1843-1922) noted that the contemporary Buddhist world was "printing and circulating their books, as the Christians do," while "European and American scholars are making accessible ... the ancient texts, and are even beginning to translate them into European languages," which would advance knowledge and scholarship (Rhys Davids 1900: 520,523 ). It is noteworthy that the Orientalist scholar saw this progress in Buddhology as a result of Asian Buddhists starting to utilize Western-style historical studies and "imitate our methods" (Rhys Davids 19oo: 524). Positively quoting Arthur Schopenhauer (1788-186o), Rhys Davids also depicted the Four Noble Truths as "the system of self-training in ethical culture," and asserted that the religion's "views of life, of philosophy, of ethics" would fit the "practical Western mind," only when "the texts have been properly edited, fully translated, so studied and summarized that they have been made accessible to every one [sic] interested in questions of philosophy and ethics" (Rhys Davids 1900: $5^{26}$ ).

These discourses on Buddhism and their conviction about the reliability of historical and textual methods reveal that the Western understanding of the religion depended heavily on both sacred texts and historical studies, and that they were confident that "textualism" would enable them to comprehend a culturally-unbound — and thus pure and original—Buddhism, as opposed to the tradition's East Asian Mahayana offshoots. According to Rhys Davids, "the 
study of later Buddhism ... is only second in importance to the study of Buddhism" (Rhys Davids 1881: 191). Oxford philologist Friedrich Max Müller (19231900) noted that the Mahayana sutras in Japan "are all, nearly all, Chinese translations of Sanskrit originals. Many of these translations, however, are known to be very imperfect" (Müller 1884: 184). Considering these influential scholars' common stress on the origins of Buddhism instead of the historical development of the religion, it is notable that Suzuki, together with his wife Beatrice, commenced the Eastern Buddhist with a masthead on every issue calling it an "unsectarian magazine devoted to the study of Mahayana Buddhism."12

Let us now examine Suzuki's English works in light of another Orientalist scholar who was also following the trend of "textualism." Despite Younghusband's keen interest in inviting Suzuki, Arthur Waley's (1889-1966) anonymous review of Essays in Zen Buddhism critically pointed out that the tone of the book was "half scholarly, half propagandist" and that Suzuki's Zen history chapter was "the weakest" because he was "unaware of Pelliot's research" and "unfamiliar with the important Zen documents at the Bibliothèque Nationale" (Waley 1927: 579). ${ }^{13}$ Although Suzuki had mentioned Dunhuang as early as 1910, he did not then notice the relationship to early Zen (Hasunuma 2020: 234). In his analysis, Barrett concluded that this harsh review probably prompted Suzuki to study the Dunhuang manuscripts and eventually led him to meet with Hu Shih (1891-1962) (Barrett 1989: 117; Kirita 2005: 86, 89). Three decades later, Waley again described Suzuki's Zen essays as "propaganda," this time with the following note in parentheses: "I am not using the word [propaganda] in any derogatory sense" (Waley 1955: 75). Put differently, Suzuki's style of primarily citing Chinese versions of Zen texts, with relatively little mention of Western academia or Sanskrit texts, could mean that "half scholarly" when dealing with existential religious experiences was "half propagandist" from the Orientalist's philological point of view. ${ }^{14}$

Kenneth Scott Latourette (1884-1968), an American historian and former Christian missionary to China, reviewed Suzuki's A Brief History of Early Chinese Philosophy (1914) less critically than Waley, concluding that, "while written in an English style which leaves much to be desired, [it] presents in an apprecia-

12 For another group that published on Mayahana Buddhism in English, the Mahāyāna Association that published the Mahayanist, see Yoshinaga (2011).

13 For the authorship of this review, see Barrett (1989: 116-121). Suzuki, probably mistakenly, assumed the anonymous reviewer was Hu Shih.

14 Sakaida recently uncovered that, when Suzuki met with the Chinese Chan monk Daxing 大醒 (1900-1950) in 1935, both agreed that Hu Shih "lacked faith" in Buddhism and, hence, did not fully understand the essence of Buddhism (Sakaida 2019: 40). 
tive yet fair manner a compact account of Chinese philosophy which is of value to the thoughtful student, whether he be a beginner or an expert" (Latourette 1921: 709). ${ }^{15}$ A German scholar of Zen Buddhism and missionary to Japan, Heinrich Dumoulin (1905-1995), similarly wrote a more positive review of Zen Buddhism and Its Influence on Japanese Culture (1938). ${ }^{16}$ The Jesuit scholar began his essay by introducing Suzuki, saying that he "has devoted a lifetime of scientific labour to the task of introducing a European public to the world of Zen" (Dumoulin 1940: 323 ). ${ }^{17}$ Interestingly, Dumoulin pointed out that some aspects of Japanese religion were missing in this book—namely, the influence of Shintō (Dumoulin 1940: 324).

It is crucial to examine Suzuki's approach to Shintō-related issues within the historical context. Based on Suzuki's English essay on Shintō in 1923 and other social critiques published under censorship, it is safe to say he was critical of state-sponsored Shintō, unlike other contemporary Buddhists and scholars who uncritically praised this modern formation of Shintō (Moriya 2012: 417419). He wrote in the English essay, "In spite of all the reasoning advanced by the government and backed by a certain class of official scholars, the Shinto of bureaucratic imperialism has no sound philosophy to support its ethical ideals of so-called national morality" (Suzuki 2016c: 69). The "national morality" was most likely a reference to the Imperial Rescript on Education that functioned as a especially commanding ideology in pre-war Japan, as Suzuki had railed against it from his youth (Moriya 2012: 419-420). 18

As in James Dobbins' description of Suzuki's Japanese Spirituality (Nihonteki reisei 日本的霊性, 1944), despite Suzuki's ambiguous stance about whether every country and culture other than Japan has "a reisei inherent in it," "it is fair to say that Japan's spiritual evolution and consciousness are at the heart of Suzuki's exposition here" (Dobbins 2015:116). Suzuki's preference for reisei over seishin 精神, together with his lengthy explanation in the preface to Japanese Spirituality, is better understood from the historical context (Dobbins 2015:116). As the historian Tsuda Sōkichi 津田左右吉 (1873-1961) observed, the ambiguous term Nihon seishin 日本精神 was trending in the 1930s, but due to the

15 This book was originally published as a series of articles in The Monist 17(3), 18(2), and 18(4) in 1907-1908. Excerpts from the essay are included in Suzuki 2016b.

16 It was later re-published as Zen and Japanese Culture with some editing as volume LXIV of the Bollingen Series in 1959. For details, see Jaffe (2010).

17 It is intriguing that scholars who focus on Suzuki's Zen philosophy tend to give largely positive evaluations. See Yanagida (1974); Ueda and Okamura (2002); and Mizuno (2019).

18 Currently, I have no evidence with which to determine whether he was interrogated or pressured for publicly reproaching Shintō, but it is possible that the Home Ministry did not consider foreign language publications as constituting a national threat. 
fact that it spread during a period of political turmoil, the related propaganda tended to "exaggerate" and was sometimes "gloomily oppressive" (Tsuda 1934: 2).

Although Tsuda was not explicit, the Shōwa Restoration movement was the driving force of the Nihon seishin ideology. Kihira Tadayoshi 紀平正美 (18781947), one of the promotors of the ideology, "never sat zazen" but based his concept of seishin on his idiosyncratic reading of the Gateless Gate (Mumonkan; Ch. Wumenguan). Kihira further dared to write a commentary insisting that "from our viewpoint, Mahayana Buddhism is supposed to be nationalistic" (Kihira 1918: 1-7, 78). Meanwhile, Suzuki's peculiar historiography of reisei, which contains no mention of Prince Shōtoku, was quite different from Watsuji Tetsurō 和辻哲郎's (1889-1960) Nihon seishinshi kenkyū日本精神史研究 (Study in the History of Japanese Spirit), which detailed the ancient "political ideal" under the reign of the imperial family in the first chapter (Watsuji 1926). Given Shin Buddhist scholars' penchant for the prince whom their founder Shinran 親鸞 (1173-1263) admired, it is also remarkably unusual for an Otani University professor like Suzuki to leave him out of a book chapter on the Pure Land Buddhism. In other words, when examining his works, one needs to delve into the themes that other contemporary scholars took for granted, but that Suzuki questioned, rather than literally interpreting his works in isolation.

Recent academic work has described Suzuki's presentation of Zen and Buddhism, especially in relation to his interaction with the Westerners, as "Buddhist modernism" or "Zen apologetics" (McMahan 2008: 6; Josephson 2012: 248). As Yoshinaga Shin'ichi summarized, however, Suzuki's discourses can be better understood as a "product of exchanges between the influx of modern Western thought and the globalization of Japanese Buddhism" from multiple directions (Yoshinaga 2018: 3), rather than a one-way export of Japanese Buddhism to the West nor simply a grafting of Western philosophy onto Buddhist concepts. In this sense, it is worth turning our attention from the East-West narrative to understanding Suzuki and his interactions with Buddhists and sympathizers outside Japan. The way Suzuki disseminated Zen Buddhism to the West may be better comprehended as what Jørn Borup has called a "circular skyr effect" (Borup 2017:20) of mutual influence and adaptation of ideas and cultures, just as the Icelandic dairy staple, skyr, that spread outside the country and became less sour in taste, but was considered a healthy "superfood" in a global market. ${ }^{19}$ Such a circular effect consisted of Suzuki's exchange of ideas

19 See, for instance, Brian Oliver, "Welcome to skyr, the Viking ‘superfood' waking up Britain," 
with a wide circle of acquaintances in both Western and other Asian Buddhist countries, as well as the influence of Western and Eastern philosophy and religious movements on him.

Although categorized separately from "Buddhism" today, the "Western thought" that Yoshinaga mentioned included Swedenborgianism, Theosophy, New Thought, and other new spiritualist movements in the early twentieth century. In this sense, Suzuki's earlier encounter with these movements through his career in the United States and marriage to Beatrice Lane must have stimulated him to find better modes of expression with which to persuade potential Western sympathizers of Buddhism. In other words, Suzuki himself was not so much infused with these "Western thoughts," but rather tolerated them as a kind of skillful means through which to transmit Buddhist teachings.

Christmas Humphreys (1901-1983) was one of the sympathetic converts who met with Suzuki in 1936. Although he did not attend the Congress, he met with Suzuki several times in London. ${ }^{20}$ According to the list of exchanges and subscribers of the Eastern Buddhist compiled by Yoshinaga and Hioki Naoko, Humphreys and Suzuki must have corresponded with each other before the editors of Buddhism in England started reprinting Suzuki's Outlines of Mahayana Buddhism from 1930 to 1934. Buddhism in England, the organ of the Buddhist Lodge, was one of the periodicals received by Suzuki and preserved at his library, the Matsugaoka Bunko, from its inaugural 1926 issue until 1941 (Yoshinaga and Hioki 2018: 17). As was often the case for Western sympathizers, Humphreys first became interested in Buddhism through Theosophy, which is obvious from the first few issues of Buddhism in England's Theosophy-oriented editorial policies (Humphreys 1955: 224-225; Bluck 2006: 7; Yoshinaga and Hioki 2018: 18-20). Humphreys himself reminisced:

In the twenties of this century the Buddhist element in London was strongly rationalist and ethical, and largely concerned with the negative philosophy of 'No-God, no-soul'. Yet though at first mainly of the Theravada School, it was early affected by the interest in Buddhism shown by English Theosophists, whose forty years of teaching similar doctrines had prepared the English mind.

HUMPHREYS 1955: 225

The Guardian, 27 November 2016. https://www.theguardian.com/world/2016/nov/27/skyr -viking-superfood-waking-up-britain (accessed 16 July 2020).

They met on at least 2 and 20 July, and on 19 October (Kirita 2005: 95-98). 
As the Buddhist Society of Great Britain and Ireland had Rhys Davids as its first president when the group was established in 1907, Buddhism in the United Kingdom at the turn of the twentieth century was mainly influenced by the Theravada tradition, but also infused with Theosophy. At the age of seventeen, Humphreys became interested in Buddhism and formed "a Buddhist Centre in the Theosophical Society, of which [he] was then a member"; it was renamed the Buddhist Lodge in 1924 and then "seceded from the Theosophical Society and became independent" in 1926 (Humphreys 1955: 225). Theosophical aspects in the British journal gradually faded away, as can be seen when it ran an essay by Beatrice Lane Suzuki dealing with the differences between Zen meditation, Theosophy, and New Thought in the $193^{2}$ issue (Yoshinaga and Hioki 2018: 20). Thus, Suzuki was well aware of the Theosophist-leaning perception of Buddhism in the West and, together with Beatrice, they sought to find a clearer means through which to disseminate Buddhism in Western languages (Moriya 2020: 155-156; Yoshinaga 2018: 1-3).

Suzuki's work on Zen was also noticed by the theologian Rudolf Otto (18691937). Hioki has recently discovered that Otto praised the Eastern Buddhist Society's activities in Die Christliche Welt (November 5, 1925). A copy of the November 1925 issue of the periodical preserved at the Matsugaoka Bunko even had Otto's signature on the cover (Hioki 2018), demonstrating the personal nature of Suzuki's exchanges with Otto. ${ }^{21}$ Hioki also pointed out that Suzuki admitted that his study of the Heart Sutra had started partly as a critical response to the concept of the numinous in Otto's the Idea of the Holy and, in 1924, the Eastern Buddhist ran an article titled "Professor Rudolf Otto on Zen Buddhism" (Hioki 2018; Suzuki 20o1b: 154-156). Suzuki later used Otto's works as textbooks for his seminars at Otani University from 1932 to 1935 (Kirita 2005: $79-90) \cdot{ }^{22}$

As Essays in Zen Buddhism was a compilation of articles originally published in the Eastern Buddhist in its first and subsequent issues, Suzuki's comparative approach to depicting the "essence" of Zen might have attracted the German scholar's interest. Otto's article, translated into English by someone using the pen name Prajñā, compared pictures of Bodhidharma with a chapter on the

21 I appreciate Dr. Hioki for generously sharing her findings from this research. The title of her presentation was different from the later printed version (Hioki 2019). For more on the periodicals that were kept at the Bunko, see Yoshinaga and Hioki (2018).

22

He also used William James' Varieties of Religious Experience in 1932 and 1933 (Kirita 2005: 79, 84). I will not go further here, but the Eastern Buddhist also carried articles by the German Buddhist Bruno Petzold on Tendai from 1923 and German-language articles by the Jōdoshū scholar Ōhashi Kaishun 大橋戒俊 on Chinese Buddhism from 1934. 
"Element of Fascination" in The Idea of the Holy, stating: "That this seated person seeks a something, which matters above everything, compared with which all things are viewed with unconcern, a something in word such as only the Numinous itself has, springs directly to the mind" (Otto 1924: 118). The article may seem to be "more or less a recapitulation of Professor Suzuki's paper on Zen" as Prajñā noted, but what is interesting is Otto's appreciation of the paradoxical logic of Zen. ${ }^{23}$

We also see Suzuki's comparative approach in his 1922-1923 essays introducing Brother Lawrence of the Resurrection's mystic experience and his "rejection of the abuse of discriminating intellect" ( funbetsu chi 分別智); ${ }^{24}$ as well as equating the French lay brother's religious practice to the instruction in the Zenmon hōkun 禅門宝訓's (Ch. Chanmen baoxun), their interests in exploring the common religious experiences shared by the East and West would certainly resonate with each other (Suzuki 2001a: 280,284$).{ }^{25}$ Suzuki cited an aphorism of studying Buddhism with a constantly determined mindotherwise, the practitioners would easily lose themselves in worldly affairs. Brother Lawrence searched diligently for what it was like to truly act for the love of God and embrace tariki 他力 or the Other Power. Suzuki praised the Carmelite friar's simple-heartedness and how he was relieved from unnecessary anxieties through his everyday chores in the kitchen, like the head cook (tenzo 典座) at a Zen monastery (Suzuki 2001a: $282-283$ ).

\section{Conclusion}

Dealing with the history of Buddhism in Germany and Europe in general, Baumann described how it spread among limited numbers of intellectuals and artists in the eighteenth and nineteenth centuries, unlike in North America, where tens of thousands of Asian immigrants brought their Buddhist tradition to the New World. Buddhism in Europe was "philosophy and ethics," which also

23 I have no evidence to prove this point, but this Prajñā could be Beatrice Lane Suzuki, as she was fluent in German. Beatrice had a German stepfather and studied in Germany in her youth. See also his letter to Beatrice dated 24 April 1938, referring to her fluency in German (sDz 36: 648).

24 Suzuki quoted the Carmelite friar's story from Talks to Teachers on Psychology by William James (James 1899).

25 The essays, “Anja Rōrensu” 行者ローレンス, were originally written for the Chūgai nippō 中外日報 on 22 November 1922 and 1 January 1923, and then compiled as a book chapter for Hyakushū sensetsu 百醜千拙 (Kyoto: Chūgai Shuppan, 1925). Zenmon hōkun is better known as Zenrin hōkun 禅林宝訓 (Ch. Chanlin baoxun). 
reflects Humphreys' account of the early history of Buddhism in England. "In fact," Baumann continued, "many of these early Buddhists approached Buddhism as little more than a hobby which left their lives, in all other respects, unchanged" (Baumann 1997: 275). As the teachings were accepted through either philosophical or philological discourses, Waley's reaction to Suzuki was inevitable in light of Western academia.

Humphreys, too, perceived Buddhist influence until the mid-twentiethcentury Europe to be relatively insignificant, as Buddhists in England were scattered and did not necessarily form organized sangha like the Christian churches. Humphreys' analysis of this issue offers an interesting overview. Here I would like to offer a rather lengthy quote:

The West will never be 'Buddhist', and only the most unthinking zealot would strive to make it so. The Western mind will never be content with second-hand clothing, and all that Western Buddhists have the right to do is to proclaim the Dhamma to all who have 'ears to hear', and to suggest why, and in principle how, it should be applied. It may be that from the mingling streams of the Pali canon, the compassionate splendour of the Mahayana and the astringent force of Zen will come a Navayana, a new 'vehicle' of salvation ... [Leading] thinkers increasingly express their own discoveries in Buddhist guise ... It may be, on the other hand, that Buddhism can better serve the West by offering, not the ready-made cathedral of a new philosophy, but the cut and well-used stones of Buddhist principles, to be built into the temple of Western thought as the awakening mind of the West has need them.

HUMPHREYS 1955: 230-231

Humphreys perceived the contemporary Western "awakening mind" as eclectic and prone to choose from "the store of Buddhist truths" (Humphreys 1955: 231). Sociologists of religious market theory would no doubt approve his statement (Stark and Bainbridge 1987), but what is necessary for my argument here is that the acculturation of Buddhism and its teachings has always taken place. According to Jaffe, despite the well-known fact that Suzuki at times "expressed great frustration about the failure of Westerners to grasp what he was trying to transmit about Zen, ... Suzuki, late in life, called for a contemporary 'Bankei' who 'has been trained in the mold and then decides to go forward on his own'" (Jaffe 2015: lv-lvi). In fact, Suzuki was anticipating "someone among the Westerners who has the strength to do this" (Suzuki and Ueda 1979: 109).

This effectively explains the reason for his being a prolific writer of Buddhism in English. As previously mentioned, Suzuki connected with Senzaki 
Nyogen starting in the 1930s and repeatedly sent-at Senzaki's request—what he referred to as a "manual," which was possibly the Manual of Zen Buddhism (1935) or perhaps the Training of the Zen Buddhist Monk (1934), to Los Angeles. ${ }^{26}$ In this sense, Suzuki wrote these articles and books and delivered the speeches and lectures in English with a kind of missionary-minded spirit despite himself remaining a lay Buddhist. Although I cannot fully examine his correspondence with Buddhists and sympathizers outside Japan, it surely demonstrates how these interactions served as a context for Suzuki's work on Buddhism.

To conclude, I refer to Suzuki's 1936 speech on the "Supreme Spiritual Ideal" that he delivered in a relaxed, humorous manner. He began his talk, "When I was first asked to talk about the Supreme Spiritual Ideal I did not exactly know what to answer. Firstly, I am just a simple-minded countryman from a far-away corner of the world suddenly thrust into the midst of this hustling city of London" (Suzuki 1936c: 432). The audience was probably amazed to hear this, and he went on to describe how Japanese people appreciate nature in the countryside. Yet, he then raised a question about facing "actualities" starkly: No matter how the participants argued about the Supreme Spiritual Ideal or religious harmony, how many people in the busy streets of London would pursue the paths discussed here? As in his previous address, he did not support "mere talking" and brought up the problem of dualistically contrasting spirituality to the material, because "As long as man is the work of nature and even the work of God, what he does, what he makes, cannot altogether be despised as material and contrasted to the so-called spiritual" (Suzuki 1936c: 434-436). Suzuki's "spiritual-material" cannot be found objectively, he said, but he encouraged the audience to "find it in our subjective minds and work it out so as to transform the entire world in accordance with it" (Suzuki 1936c: 436).

He concluded his talk with a casual and amusing reference to case fifty-two of the Blue Cliff Record, known as Jōshū toro toba 趙州渡驢渡馬 (Jōshū's Stone Bridge for Donkeys and Horses). One day a monk asked Jōshū (Ch. Zhaozhou) where the fine stone bridge was. Suzuki went on as follows:

... the Master now answered this way: "You only see that miserable, rickety plank and don't see the stone bridge?" The disciple said: "Where is the stone bridge then?" And this was the Master's answer: "Horses pass over it, donkeys pass over it, cats and dogs ..." (Excuse me if I add a little more than the master actually said) — "Cats and dogs, tigers and ele-

26 Suzuki to Senzaki, (29 October 1934?), 18 January (year unknown), 23 May (1940?), 14 August 1938, 25 April (1938?). Folder 1, Nyogen Senzaki Papers, Box 3, Zen Studies Society Archives. 
phants pass over it, men and women, the poor, and the rich, the young and the old, the humble and the noble (any amount of those opposites might be enumerated); Englishmen, perhaps Japanese, Muslims, Christians; spirituality and materiality, the ideal and the practical, the supreme and the most commonplace things ... The stone bridge lies flat and goes on silently from the beginning-less past perhaps to the endless future."

SUZUKI 1936c: 437

Our "subjective minds" that see the egalitarian stone bridge before us probably arises from the Buddhist Supreme Ideal (i.e., Śünyatā). Contrary to this egalitarian ideal, however, Ignorance in real life overwhelmingly affected people's dualistic mindset and functioned to discriminate between different races, ethnicities, nationalities, or religions. ${ }^{27}$ History also witnessed Germany and Italy signing a protocol in October 1936, followed by the Anti-Comintern Pact between Germany and Japan the next month, the conclusion of the Axis alliance in 1939, and the Tripartite Pact in 1940. The stone bridge would seem to have collapsed from the storm of the war but, according to Suzuki, Buddhism would "face its dualism, its evils, its struggles, [and] its pains," and his seemingly optimistic wish for "Spiritual World Fellowship" would drive him to pursue the Buddhist way in the most critical years of his life (Suzuki 1936c: 437). For Suzuki, being aware of discriminative Ignorance, even "subjective minds" rooted in śünyatā could see equality in human existence, transcending the dualistic conditions that divide us.

\section{Acknowledgments}

I would like to acknowledge that this article was supported by JSPS KAKENHI Grant Numbers JP2OHO1192 and JP17Ko2238, and the Research Grants in the Humanities from the Mitsubishi Foundation. I also wish to thank the insightful

27 Although not my main theme of discussion here, in his travel report, Suzuki wrote sympathetically about a wealthy young Jewish poet who left Germany to escape persecution. He met the poet in England and knew that thousands of Jewish asylum-seekers had already fled to the United Kingdom. Although the travel report naively explained how local Germans supported the Nazis and analyzed the psychology of their discrimination against the Jewish people, Suzuki did not praise the xenophobic, racist rally in Nuremberg or the news media that uncritically disseminated these conspiracy theories (Suzuki 2002: 216-217). He also critically categorized supporters of Fascism, Nazism, imperialism, and Bolshevism as "irrational" and the "embodiment of 'coercive force" (Suzuki 2012b: 245). 
comments and suggestions of participants at the Seminar on Japanese Buddhism in Europe at Aarhus University, particularly Jørn Borup and Elisabetta Porcu, and an anonymous referee for the Journal of Religion in Japan. Research at the Zen Studies Society Archives was made possible by generous support from the people at the New York Zendo Shōbōji, Richard M. Jaffe, and Michael J. Conway, for all of which I am grateful.

\section{Abbreviation}

SDZ Hisamatsu Shin'ichi 久松真一, Yamaguchi Susumu 山口益, et al. (eds.). 1999-2003. Suzuki Daisetsu zenshū 鈴木大拙全集, 40 vols. Tokyo: Iwanami Shoten.

\section{References}

Almond, Philip C. 1988. The British Discovery of Buddhism. Cambridge: Cambridge University Press.

Andō, Reiji 安藤礼二. 2018. Daisetsu 大拙. Tokyo: Kōdansha.

Arnold, Edwin. 1998 [1879]. The Light of Asia, or the Great Renunciation. Adyar and Wheaton: Theosophical Society.

Barrett, Timothy H. 1989. "Arthur Waley, D.T. Suzuki and Hu Shih: New Light on the 'Zen and History' Controversy." Buddhist Studies Review 6(2):116-121.

Baumann, Martin. 1997. "Culture Contact and Valuation: Early German Buddhists and the Creation of a 'Buddhism in Protestant Shape." Numen 44(3): 270-295.

Berdiaeff, Nicolas. 1936. "The Brotherhood of Man and the Religions." In Faiths and Fellowship: Being the Proceedings of the World Congress of Faiths held in London, July 3 rd-17th, 1936, ed. Douglas A. Millard, London: J.M. Watkins, $75^{-84}$.

Bluck, Robert. 2006. British Buddhism: Teachings, Practice, and Development. London and New York: Routledge.

Borup, Jørn. 2017. "Pizza, Curry, Skyr and Whirlpool Effects: Religious Circulations Between East and West." In Eastspirit: Transnational Spirituality and Religious Circulation in East and West, eds. Jørn Borup and Marianne Qvortrup Fibiger, Leiden: Brill, $13-35$.

Dobbins, James C. 2015. "Introduction to Selections from Japanese Spirituality." In Selected Works of D.T. Suzuki, vol. 2 Pure Land, ed. James C. Dobbins, Oakland: University of California Press, 115-117.

Dumoulin, Heinrich. 1940. "Zen Buddhism and its Influence on Japanese Culture. by Daisetz Teitarō Suzuki." Monumenta Nipponica 3(1): 323-325. 
Eastern Buddhist Society. 1922. "Notes," Eastern Buddhist 1(5-6): 391-399.

Faure, Bernard. 1995. "The Kyoto School and Reverse Orientalism." In Japan in Traditional and Postmodern Perspectives, eds. Charles Wei-hsun Fu and Steven Heine, Albany: State University of New York Press, 245-281.

Hasunuma, Chokuyō 蓮沼直應. 2020. Suzuki Daisetsu: Sono shisō kōzō 鈴木大拙一そ の思想構造. Tokyo: Shunjūsha.

Hioki, Naoko 日沖直子. 2018. “'Unsectarian’ zasshi The Eastern Buddhist: 1920 nendai kōhan no kōdokusha, kōkan teikei zasshi risuto o megutte” 'Unsectarian' 杂倠誌 The Eastern Buddhist: 1920年代後半の購読者・交換提携雑誌リス卜をめぐって. Paper presented at the panel, "Tōzai o ōkan suru kindai Bukkyō: Suzuki Daisetsu to sono shūhen” 東西を往還する日本仏教一鈴木大拙とその周辺, the 77th Annual Meeting of the Nihon Shūkyō Gakkai, Otani University, 9 September.

Hioki, Naoko 日沖直子. 2019. "The Eastern Buddhist dai-ikki no kōdokusha risuto ni tsuite” The Eastern Buddhist 第一期の購読者リストについて. Shūkyō kenkyū bessatsu 宗教研究別冊 92 Supplement: 82-83.

Humphreys, Christmas. 1955. Buddhism [revised edition]. Harmondsworth: Penguin Books.

Iijima, Takayoshi 飯島孝良. 2019. “Suzuki Daisetsu wa Nihon ni okeru zenseki juyō o dō kangaete itanoka: Zen shisōshi kenkyū o chūshin ni” 鈴木大拙は日本における禅 籍受容をどう考えていたのか一『禅思想史研究』を中心に. Kindai bukkyō 近代仏教 26: $75^{-98}$.

Iwakura, Masaji 岩倉政治. 1995. Shin'nin Suzuki Daisetsu 真人 鈴木大拙. Kyoto: Hōzōkan.

Jaffe, Richard M. 2010. "Introduction to the 2010 Edition." In Zen and Japanese Culture, by Daisetz T. Suzuki, Princeton: Princeton University Press, vii-xxviii.

Jaffe, Richard M. 2015. "Introduction." In Selected Works of D.T. Suzuki, vol. 1 Zen, ed. Richard M. Jaffe, Oakland: University of California Press, ix-lvi.

Jaffe, Richard M. 2018. "D.T. Suzuki and the Two Cranes: American Philanthropy and Suzuki's Global Agenda." Matsugaoka bunko kenkyū nenpo 松ヶ岡文庫研究年報 32: 29-58.

James, William. 1899. Talks to Teachers on Psychology: And to Students on Some of Life's Ideals. Boston: Geo. H. Ellis.

Josephson, Jason Ānanda. 2012. The Invention of Religion in Japan. Chicago: University of Chicago Press.

King, Richard. 1999. Orientalism and Religion: Postcolonial Theory, India and "The Mystic East." London and New York: Routledge.

Kihira, Tadayoshi 紀平正美. 1918. Mumonkan kaishaku 無門関解釈. Tokyo: Iwanami Shoten.

Kirita, Kiyohide 桐田清秀 (ed). 2005. Suzuki Daisetsu kenkyū kiso shiryō 鈴木大拙研究 基礎資料. Kamakura: Matsugaoka Bunko. 
Kirita, Kiyohide (ed.). 2011. “D.T. Suzuki's English Diaries VII. 1936 to 1938." Matsugaoka bunko kenkyū nenpō 松ヶ岡文庫研究年報 25: 1-85.

Latourette, Kenneth Scott. 1921. "Chinese Historical Studies during the Past Seven Years." American Historical Review 26(4): 703-716.

McMahan, David L. 20o8. The Making of Buddhist Modernism. Oxford: Oxford University Press.

Magnes, Judah Leon. 1936. "The Spirit of Peace and the Spirit of War." In Faiths and Fellowship: Being the Proceedings of the World Congress of Faiths held in London, July $3 r d-17 t h$, 1936, ed. Douglas A. Millard, London: J.M. Watkins, 264-269.

Mizuno, Tomoharu 水野友晴. 2019. “Sekaiteki jikaku” to “Tōyō”: Nishida Kitarō to Suzuki Daisetsu「世界的自覚」と「東洋」一西田幾多郎と鈴木大拙. Tokyo: Kobushi Shobō.

Moriya, Tomoe 守屋友江. 2005. "Social Ethics of 'New Buddhists' at the Turn of the Twentieth Century: A Comparative Study of Suzuki Daisetsu and Inoue Shūten." Japanese Journal of Religious Studies 32(2): 283-304.

Moriya, Tomoe 守屋友江. 2012. "Kaisetsu bukkyōsha Suzuki Daisetsu: Sono gudō no ato o tadoru 解説 仏教者鈴木大拙一その求道の跡をたどる.” In Zen ni ikiru: Suzuki Daisetsu korekushon 禅に生きる一鈴木大拙コレクション, ed. Moriya Tomoe 守屋友 江, Tokyo: Chikuma Shobō, 413-428.

Moriya, Tomoe 守屋友江. 2020. “Daisetsu to Biatorisu no sentaku” 大拙とビアトリスの 選択. Gendai shisō 現代思想 48(15): 155-164.

Müller, Friedrich Max. 1872. Lectures on the Science of Religion: With a Paper on Buddhist Nihilism, and a Translation of the Dhammapada or "Path of Virtue." New York: Charles Scriber.

Ogawa, Takashi 小川隆. 2011. Goroku no shisōshi: Chügoku Zen no kenkyū 語録の思想 史一中国禅の研究. Tokyo: Iwanami Shoten.

Otto, Rudolf. 1924. "Professor Rudolf Otto on Zen Buddhism.” Trans. Prajñā (pseud.), The Eastern Buddhist 3(2): 117-125.

Oliver, Brian. 2016. "Welcome to Skyr, the Viking 'Superfood' Waking up Britain.” The Guardian, 27/11/2016. https://www.theguardian.com/world/2016/nov/27/skyr-vikin g-superfood-waking-up-britain (accessed 16 July 2020).

Rhys Davids, Thomas W. 1881. Lectures of the Origin and Growth of Religion as Illustrated by Some Points in the History of Indian Buddhism. London: Williams and Norgate.

Rhys Davids, Thomas W. 19oo. "Buddhism," North American Review 171(527): 517-527.

Sakaida, Yukiko 坂井田夕起子. 2019. "Chūgokujin sōryo no mita kindai Nihon Bukkyō: Daxing no Nihon Bukkyō shisatsuki o chūshin ni” 中国人僧侶の見た近代日本仏 教一大醒の『日本仏教視察記』を中心に. Kindai bukkyō 近代仏教 26: 75-98.

Sharf, Robert. 1993. “The Zen of Japanese Nationalism." History of Religions 33(1): 1-43. Stark, Rodney and William Sims Bainbridge. 1987. A Theory of Religion. New Brunswick: Rutgers University Press.

Suzuki, Daisetz Teitaro. 1921. “Why Do We Fight?” The Eastern Buddhist 1(4): 270-281. 
Suzuki, Daisetz Teitaro. 1932. The Lankavatara Sutra: A Mahayana Text. London: Routledge.

Suzuki, Daisetz Teitaro. 1936a. "Ignorance and World Fellowship." In Faiths and Fellowship: Being the Proceedings of the World Congress of Faiths held in London, July 3 rd17th, 1936, ed. Douglas A. Millard, London: J.M. Watkins, 34-47.

Suzuki, Daisetz Teitaro. 1936b. "Discussion." In Faiths and Fellowship: Being the Proceedings of the World Congress of Faiths held in London, July 3rd-17th, 1936, ed. Douglas A. Millard, London: J.M. Watkins, 53.

Suzuki, Daisetz Teitaro. 1936c. “Supreme Spiritual Ideal." In Faiths and Fellowship: Being the Proceedings of the World Congress of Faiths held in London, July $3 r d-17$ th, 1936, ed. Douglas A. Millard, London: J.M. Watkins, 432-437.

Suzuki, Daisetz Teitaro. 2016a (1896). "Selections from Shin shūkyō ron (A New Interpretation of Religion)." In Selected Works of D.T. Suzuki, vol. 3 Comparative Religion, eds. Jeff Wilson and Tomoe Moriya, Oakland: University of California Press, 3-28.

Suzuki, Daisetz Teitaro. 2016b (1907). "A Brief History of Early Chinese Philosophy." In Selected Works of D.T. Suzuki, vol. 3 Comparative Religion, eds. Jeff Wilson and Tomoe Moriya, Oakland: University of California Press, 41-51.

Suzuki, Daisetz Teitaro. 2016c (1923). "A Contemporary Buddhist View of Shinto." In Selected Works of D.T. Suzuki, vol. 3 Comparative Religion, eds. Jeff Wilson and Tomoe Moriya, Oakland: University of California Press, $65^{-72}$.

Suzuki, Daisetz Teitaro. 2016d (1961). "Wisdom in Emptiness." In Selected Works of D.T. Suzuki, vol. 3 Comparative Religion, eds. Jeff Wilson and Tomoe Moriya, Oakland: University of California Press, 201-225.

Suzuki, Daisetsu Teitarō 鈴木大拙貞太郎. 1936d. Kōkan Shōshitsu issho oyobi kaisetsu 校刊少室逸書及解説. Osaka: Ataka Bukkyō Bunko.

Suzuki, Daisetsu Teitarō 鈴木大拙貞太郎. $2001 a$ (1925). Hyakushū sensetsu 百醜千拙. SDZ 17, 193-316.

Suzuki, Daisetsu Teitarō 鈴木大拙貞太郎. 2001 b (1941). Zen no shomondai 禅の諸問題. SDZ 18, 3-241.

Suzuki, Daisetsu Teitarō 鈴木大拙貞太郎. 2002 (1936). “Rain kahan no ichigū kara” ラ イン河畔の一隅から. SDZ 32, 208-219.

Suzuki, Daisetsu Teitarō 鈴木大拙貞太郎. 2012a (1930). “Binbōnin to shūkyō” 貧乏人と 宗教. In Zen ni ikiru: Suzuki Daisetsu korekushon 禅に生きる一鈴木大拙コレクション, ed. Moriya Tomoe 守屋友江, Tokyo: Chikuma Shobō, 203-205.

Suzuki, Daisetsu Teitarō 鈴木大拙貞太郎. 2012b (1943). “Sakuma Shōzan o shinobite: Chisei gata to jōi gata no ningen” 佐久間象山を偲びて一知性型と情意型の人 間. In Zen ni ikiru: Suzuki Daisetsu korekushon, ed. Moriya Tomoe 守屋友江, Tokyo: Chikuma Shobō, 244-252.

Suzuki, Teitarō 鈴木貞太郎 (ed.). 1935. Tonkō shutsudo Shōshitsu issho 燉煌出土少室 逸書. Kyoto: Suzuki Teitarō. 
Suzuki, Daisetz 鈴木大拙 and Ueda Shizuteru 上田閑照. 1973. “The Sayings of Rinzai: A Conversation between Suzuki Daisetz \& Ueda Shizuteru." The Eastern Buddhist Ns 6(1): 92-110.

Takahashi, Hara 高橋原. 20o9. “Anesaki Masaharu no Kokusai Renmei enzetsu (1936 nen)”姉崎正治の国際連盟演説 (1936年). Tōkyō Daigaku shūkyōgaku nenpō bessatsu 東京大学宗教学年報別冊 26: 9-12.

Tsuda, Sōkichi 津田左右吉. 1934. “Nihon seishin ni tsuite” 日本精神について. Shisō 思 想144: 2-20.

Ueda, Shizuteru 上田閑照and Okamura Mihoko 岡村美穂子 (eds.). Suzuki Daisetsu to wa dare ka 鈴木大拙とは誰か. Tokyo: Iwanami Shoten.

Van Ryswyck, J. John. 1936. “Discussion." In Faiths and Fellowship: Being the Proceedings of the World Congress of Faiths held in London, July $3{ }^{2}-17$ th, 1936, ed. Douglas A. Millard, London: J.M. Watkins, 53.

Victoria, Brian. 1997. Zen at War. New York and Tokyo: Weatherhill.

Victoria, Brian. 2013. "D.T. Suzuki, Zen and the Nazis." Asia-Pacific Journal 11(4) https:// apjjf.org/2013/11/43/Brian-Victoria/4019/article.html (accessed 7 August 2019).

Waley, Arthur. 1927. "Essays in Zen Buddhism (First Series). By Daisetz Teitaro Suzuki." Times Literary Supplement (25 August): 579.

Waley, Arthur. 1955. "History and Religion." Philosophy East and West 5(1): 75-78.

Watanabe, Ken'ya 渡辺健哉. 2016. “Tokiwa daijō no Chūgoku chōsa” 常磐大定の中国 調査. Tōyō bunka kenkyū 東洋文化研究 18: 31-55.

Watsuji, Tetsurō 和辻哲郎. 1926. Nihon seishinshi kenkyū 日本精神史研究. Tokyo: Iwanami Shoten.

Whale, J.S. 1936. “The City of God." In Faiths and Fellowship: Being the Proceedings of the World Congress of Faiths held in London, July 3 rd-17th, 1936, ed. Douglas A. Millard, London: J.M. Watkins, 180-19o.

Yanagida, Seizan 柳田聖山. 1974. “Zen no rekishi to goroku” 禅の歴史と語録. In Zen goroku 禅語録, ed. Yanagida Seizan 柳田聖山, Tokyo: Chūō Kōronsha, 7-78.

Younghusband, Francis Edward. 1918. "Preface." In For the Right: Essays and Addresses by Members of the "Fight for Right Movement", ed. Fight for Right Movement, New York and London: G.P. Putnam's Son, iii-vi.

Yoshinaga, Shin'ichi 吉永進一. 2011. “Uiriamu Makugavan to daijō kyōkai” ウイリアム・マ クガヴァンと大乗協会. Kindai bukkyō 近代仏教 18: 129-145.

Yoshinaga, Shin'ichi 吉永進一. 2018. “Beatrice Lane Suzuki kenkyū ni tsuite” Beatrice Lane Suzuki 研究について. Matsugaoka bunko kenkyū nenpō 松ケ岡文庫研究年報 32: 1-12.

Yoshinaga, Shin'ichi 吉永進一. 2019. “Daisetsu fusai to shinchigaku: Daisetsu eibun nikki to Biatorisu shiryō o sanshō shite” 大拙夫妻と神智学一大拙英文日記とビ アトリス資料を参照して. Matsugaoka bunko kenkyū nenpō 松ヶ岡文庫研究年報 33: 1-24. 
Yoshinaga, Shin'ichi 吉永進一and Hioki Naoko 日沖直子. 2018. “Matsugaoka Bunko miseiri shiryō yori: İsutan buddisuto shi kankei no kizō zasshi ni tsuite” 松ヶ岡文庫 未整理資料より—『イースタン・ブディスト』誌関係の寄贈雑誌について. Matsugaoka bunko kenkyū nenpō 松ヶ岡文庫研究年報 32: 13-28. 